OPEN ACCESS

Edited by:

Juan Cruz Larrasoaña, Instituto Geológico y Minero de

España, Spain

Reviewed by:

Eric Font,

University of Lisbon, Portugal

Chenglong Deng,

Chinese Academy of Sciences, China

*Correspondence: Junsheng Nie jnie@/zu.edu.cn

Specialty section

This article was submitted to Geomagnetism and Paleomagnetism,

a section of the journal

Frontiers in Earth Science

Received: 16 December 2015

Accepted: 29 February 2016

Published: 15 March 2016

Citation:

Nie J, Song Y and King JW (2016) A Review of Recent Advances in Red-Clay Environmental Magnetism and Paleoclimate History on the Chinese Loess Plateau.

Front. Earth Sci. 4:27. doi: 10.3389/feart.2016.00027

\section{A Review of Recent Advances in Red-Clay Environmental Magnetism and Paleoclimate History on the Chinese Loess Plateau}

\author{
Junsheng Nie ${ }^{1 *}$, Yougui Song ${ }^{2}$ and John W. King ${ }^{3}$ \\ ${ }^{1}$ Key Laboratory of Western China's Environmental Systems, Ministry of Education, College of Earth and Environmental \\ Sciences, Lanzhou University, Lanzhou, China, ${ }^{2}$ State Key Laboratory of Loess and Quaternary Geology, Institute of Earth \\ Environment, Chinese Academy of Sciences, Xi'an, China, ${ }^{3}$ Graduate School of Oceanography, University of Rhode Island, \\ Narragansett, RI, USA
}

The red-clay sequence on the Chinese Loess Plateau (CLP) was deposited during the late Miocene-Pliocene and is encoded with important information of past climate changes. However, it has received much less study in comparison to the overlying Pleistocene loess-paleosol sequence. In this paper, we review recent progress in characterizing the environmental magnetic parameter-based paleoclimate history recorded by the red-clay sequence. Several key conclusions are as follows. (1) the red-clay and the loess-paleosol sequences have similar magnetic enhancement mechanisms but magnetic minerals in the red-clay sequence have experienced a higher degree of oxidation than in the loess-paleosol sequence. (2) The CLP experienced a cooling and wetting trend from 4.5 to $2.7 \mathrm{Ma}$, caused by ice sheet expansion and East Asian summer monsoon intensification, respectively. (3) The above conclusions benefit from backfield remanence curve unmixing and comparison of magnetic grain size/concentration records, which are particularly useful in separating the temperature from the precipitation signal. A clear need in future studies is to explore the concentration and the grain size variations of hematite and goethite in the red-clay sequence and their formation mechanisms. The payback would be a clear understanding of climate history during the late Miocene-Pliocene, a possible analog for future warmer climate.

Keywords: red-clay, loess, environmental magnetism, Pliocene, hematite

\section{INTRODUCTION}

Loess sediments on the Chinese Loess Plateau (CLP) are products of inland Asian aridification and global cooling (Liu, 1985; Heller and Evans, 1995) and recent studies reveal that recycled northeastern Tibet-originated sediments brought by the Yellow River are also important sources for the CLP (Stevens et al., 2013; Nie et al., 2015). Therefore, these terrestrial wind-blown siltsize sediments are ideal archives for reconstructing the long-term paleoclimate history of Asia and exploring coupling mechanisms between Asian and global climate. Supra-orbital climate changes are usually caused by either tectonic forcing, or the climatic system's crossing of important climatic thresholds (Raymo, 1994; Ruddiman, 2000; An et al., 2001; Zachos et al., 2001). Therefore, long and continuous paleoclimate records are essential for studying tectonic-climate interaction mechanisms and understanding nonlinear responses of our climate system to external forcing. Furthermore, 
supra-orbital, orbital, and sub-orbital changes of our climate system are internally linked, and understanding long-term climate changes would help to better understand short-term climate changes (Huybers and Curry, 2006).

The Chinese loess can be divided into 3 sequences. The uppermost sequence is the loess-paleosol sequence, which consists of 33 paleosol and 34 loess layers for most continuous sections (Liu et al., 1999; Yang and Ding, 2010). Depositional ages of this sequence span from $\sim 2.7$ to $0 \mathrm{Ma}$ (Liu et al., 1999; Yang and Ding, 2010). Conformably underlying the loess-paleosol sequence is the red-clay sequence. The depositional ages of this sequence span from $\sim 8$ to $\sim 2.7 \mathrm{Ma}$ (Ding et al., 1998; Sun et al., 1998; Qiang et al., 2001; Song et al., 2001). A study extended the bottom age of this sequence back to $11 \mathrm{Ma}$ (Xu et al., 2009) but further research suggests a younger age $(\sim 5.2 \mathrm{Ma})$ (Anwar et al., 2015). The third sequence is only found on the western CLP, i.e., west of the Liupan Shan ("Shan" means "mountain" in Chinese; Guo et al., 2002; Hao and Guo, 2007). Depositional ages of this sequence span from $\sim 22$ to $\sim 6 \mathrm{Ma}$ and a recent study extended the bottom age of this sequence back to $25 \mathrm{Ma}$ (Qiang et al., 2011). At this time, debates exist about whether "loess sediments" older than $6 \mathrm{Ma}$ are eolian in origin or at least whether they were also affected by fluvial processes after deposition (Ding et al., 1998; Sun et al., 1998; Guo Z. T. et al., 2001; Alonso-Zarza et al., 2009). However, most researchers agree that loess sediments younger than $6 \mathrm{Ma}$ are eolian with little modification from fluvial processes (Ding et al., 1998; Sun et al., 1998; An et al., 2001; Lu et al., 2001).

Numerous magnetic studies have been done on the Quaternary loess-paleosol sequence (Kukla et al., 1988; Zhou et al., 1990; Banerjee et al., 1993; Verosub et al., 1993; Evans and Heller, 1994; Maher et al., 1994; Heller and Evans, 1995; Liu et al., 1995, 2007; Bloemendal and Liu, 2005; Deng et al., 2005). In contrast, less rock magnetic work has been done on the red-clay sequence on the CLP (Liu et al., 2003; Nie et al., 2007, 2008d, 2010; Song et al., 2007). The red-clay sequence arguably is one of the few continuous terrestrial archives for studying forcing mechanisms of Pliocene climate. Understanding the forcing mechanisms of Pliocene climate change is important because climate modelers have estimated $\sim 2-\sim 4^{\circ} \mathrm{C}$ warming by the end of this century in response to increasing $\mathrm{CO}_{2}$ inputs to the atmosphere (Kerr, 2007). The estimated future temperature is similar to that in the Pliocene (Sloan et al., 1996). In addition, a phase of strong uplift of the Tibetan Plateau has been proposed to occur during the late Miocene-Pliocene periods (Li et al., 1997; An et al., 2001), and the red-clay sequence is a very important sedimentary archive for understanding environmental effects of this possible uplift of the Tibetan Plateau. Therefore, a lack of paleoclimate history knowledge encoded in the red-clay sequence is unfortunate. It is our goal to attract more scholars to study the paleoclimate history recorded by the red-clay sequence by reviewing recent progress in red-clay environmental magnetism.

In this review, we first review the debate about the origins of the red-clay sequence. Then we move on to introduce the paleoclimate history recorded by red-clay magnetic susceptibility $(\chi)$ and evaluate its reliability. After this, we introduce the paleoclimate history recorded by red-clay magnetic grain size proxy records and magnetic unmixing techniques and evaluate their reliability. Then, we compare magnetic behavior differences between the loess-paleosol sequence and the redclay sequence. Finally, we suggest future directions in red-clay environmental magnetism studies.

\section{GEOLOGICAL SETTING OF THE CHINESE LOESS PLATEAU}

The CLP is divided into the western and eastern parts by the NWSE striking Liupan Shan, a late Neogene fold-thrust belt (Song et al., 2001; Figure 1). The Liupan Shan is a ramp anticline in the hanging wall of the east-vergent Liupan Shan thrust fault (Song et al., 2001; Zheng et al., 2006). Apatite fission track data from hanging wall of the Liupan Shan thrust fault reveal almost invariant ages of $8 \mathrm{Ma}$ below a fossil partial annealing zone, suggesting that initiation of rapid uplift and exhumation of the Liupan Shan at the same time (Zheng et al., 2006). The western CLP belongs to the Longzhong Basin, which is a Cenozoic foreland basin as a result of India-Asia collision (Horton et al., 2004). The eastern CLP belongs to the Ordos block, which is bounded by the Luliang Shan to the east, the Qinling Shan to the south, the Helan Shan to the west, and the Yin Shan to the north (Song et al., 2001). The Ordos block was lack of tectonic activities and experienced widespread erosion during the Late Cretaceous and early Cenozoic, resulting in the formation of a gently-sloped planation surface (Song et al., 2001). The planation surface was disrupted during the late Cenozoic period caused by India-Asia collision and uplift of the Liupan Shan.

\section{DEBATES ABOUT ORIGINS OF THE RED-CLAY SEQUENCE}

The red-clay sequence was originally interpreted to be either alluvial flood deposits, or lacustrine sediments that were oxidized after deposition (Andersson, 1923). Liu et al. (1988) presented the first magnetic fabric evidence suggesting an eolian origin for the upper part of the red-clay sequence (Liu et al., 1988). This viewpoint has been supported by further magnetic studies (Liu et al., 2003; Nie et al., 2007, 2008d), grain size (Ding et al., 1998; Lu et al., 2001), and geochemical evidence (Ding, 2001a). Although, there is a consensus that the upper red-clay sequence $(3.6-2.6 \mathrm{Ma})$ is eolian, no consensus has been achieved about the lower red-clay sequence. Based on grain size and rare earth element (REE) data, Ding et al. (1998) argue that the entire redclay sequence ( $\sim 7-2.6 \mathrm{Ma})$ is eolian (Ding et al., 1998). However, based on detailed soil microstructure observations, geochemistry data, and grain size data, Guo Z. T. et al. (2001) propose that the red-clay sequence older than $\sim 6 \mathrm{Ma}$ is largely water-reworked sediment resulting from either alluvial, or slope processes, with a possible minor eolian contribution, and the portion between $\sim 6$ and $\sim 3.6 \mathrm{Ma}$ is largely eolian, but was significantly affected by groundwater oscillations (Guo Z. T. et al., 2001). Unfortunately, Guo Z. T. et al. (2001)'s work was only performed in one section, so it remains to be explored if similar observations can be found for other lower red-clay sediments of similar age at different locations on the CLP. 


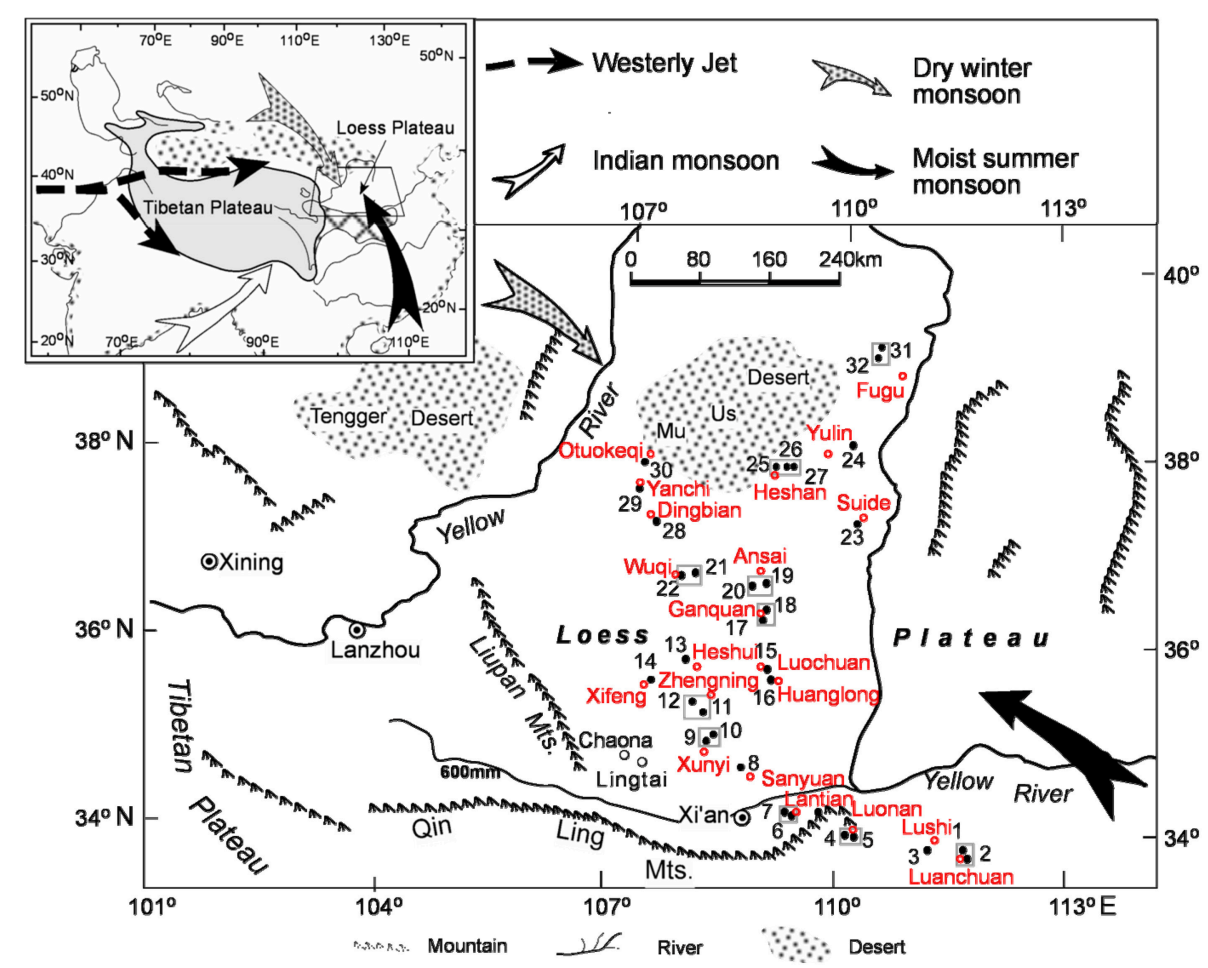

FIGURE 1 | Schematic map of the Chinese Loess Plateau and the location of the Chaona profile (black circle beneath Chaona), the Lingtai profile (black circle above Lingtai), surface soil samples (solid dots), and meteorological stations (red circles) used in this paper. The inset illustrates the location of the Chinese Loess Plateau relative to the Tibetan Plateau and the modern Asian atmospheric circulation. Magnetic parameter values were averaged for dots within the gray rectangle before comparing with the meteorological data closest to them. Modified from Song et al. (2007).

Zircon $\mathrm{U}-\mathrm{Pb}$ age distribution patterns have proven to be particularly useful for tracing the provenance of Chinese loess (Stevens et al., 2010; Pullen et al., 2011). We have generated some zircon U-Pb ages (Nie et al., 2014a) from the Chaona red-clay section (Figure 1). These data indicate that the CLP experienced a dramatic provenance shift between 8 and $5 \mathrm{Ma}$ because the zircon $\mathrm{U}-\mathrm{Pb}$ age distribution patterns of the $8 \mathrm{Ma}$ red-clay and the $5 \mathrm{Ma}$ red-clay are strikingly different (Figure 2). Considering the thermochronological evidence that supports rapid exhumation of the Liupan Shan around $8 \mathrm{Ma}$ (Zheng et al., 2006), we concur with Guo Z. T. et al. (2001) that the 8 Ma sediments on the CLP should have a contribution from either alluvial, or slope process derived material most likely from the Liupan Shan. Interestingly, the zircon $\mathrm{U}-\mathrm{Pb}$ data also reveal a likely provenance shift between 4 and 3 Ma corresponding to the onset of the intensive Northern Hemisphere glaciations (Figure 2), which might be caused by expansion of the central Asian deserts and introduction of new source areas (Nie et al., 2014a).

\section{PALEOCLIMATE HISTORY OF THE CHINESE LOESS PLATEAU RECORDED BY RED-CLAY $\chi$ AND ITS RELIABILITY}

For the loess-paleosol sequence, $\chi$ is the most widely accepted proxy for the EASM precipitation intensity (Liu, 1985; Evans and Heller, 1994; Maher et al., 1994; Heller and Evans, 1995; Liu et al., 1995, 2007; Chen and An, 1999; Heslop et al., 2000; An et al., 2001; Maher and $\mathrm{Hu}, 2006)$. Southern sites on the CLP might be an exception to this relationship between $\chi$ and rainfall probably because a high rainfall threshold is crossed that results in the diagenetic destruction of magnetic minerals responsible for magnetic enhancement (Guo B. et al., 2001; Bloemendal and Liu, 2005). However, most studies suggest that the $\chi$ records for sections on the central CLP accurately reflect rainfall variations from the EASM, at least in a qualitative sense (Guo B. et al., 2001; Bloemendal and Liu, 2005).

For the red-clay sequence, there are great debates about whether $\chi$ can be used as a proxy for the EASM precipitation intensity. Ding et al. (1999) propose that $\chi$ can't be used as a proxy to reflect the EASM precipitation intensity. They observe that between 220 and $240 \mathrm{~m}$ in their section (corresponding to $\sim 5-\sim 4 \mathrm{Ma}$ according to their paleomagnetic age model) are highly-developed paleosols characterized by thick clay skins and Fe-Mn films, but the $\chi$ of this interval is quite low, inconsistent with their field observations (Ding et al., 1999). They argue that gleying under reductive conditions could have dissolved ferrimagnetic grains produced during pedogenesis and thus $\chi$ will not be able to reflect rainfall intensity received by the CLP. However, the content of clay skins and Fe-Mn films in soils may not be solely controlled by precipitation. Other factors, e.g., pedogenic time, could also play a key role in determining the content of clay skins and Fe-Mn films. For this reason, their interpretation warrants further investigation. 


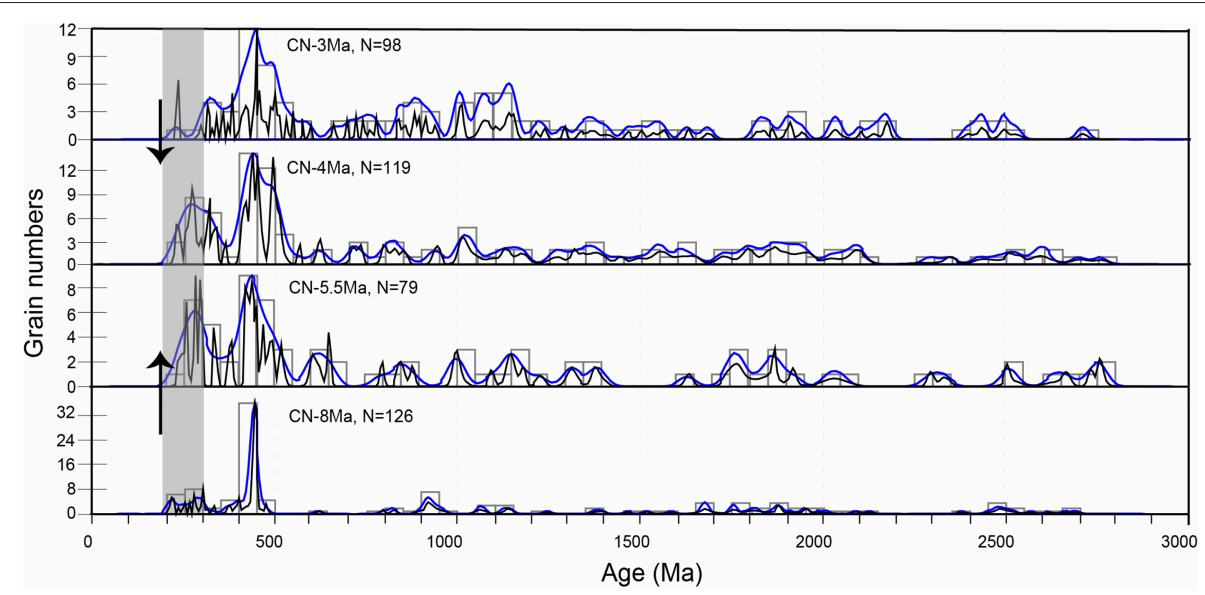

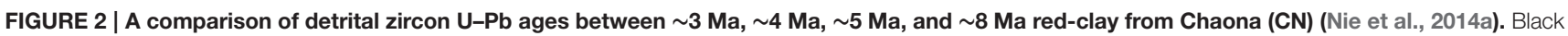
and blue lines are normalized probability density plots and Kernel Density Estimation plots, respectively, and the open rectangles are age histograms. The shaded bar marks the age range 300-200 Ma and the upward and downward arrows indicate the upsection increase and decrease of the 300-200 Ma age population,

respectively.

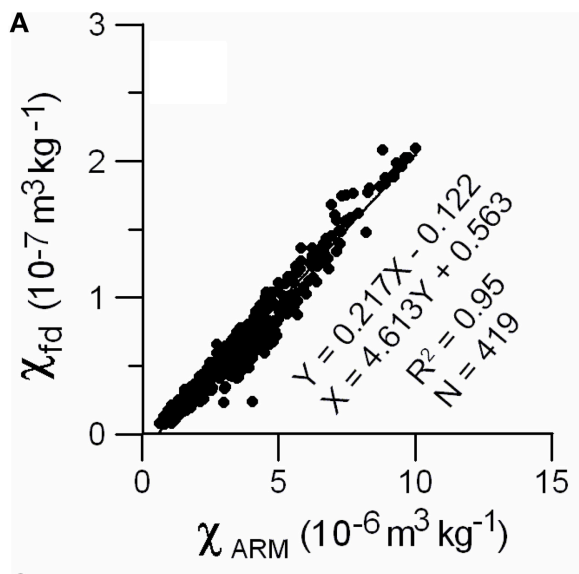

C

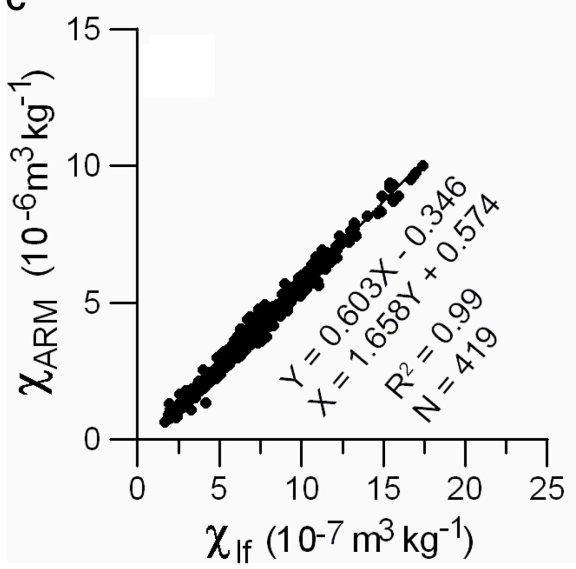

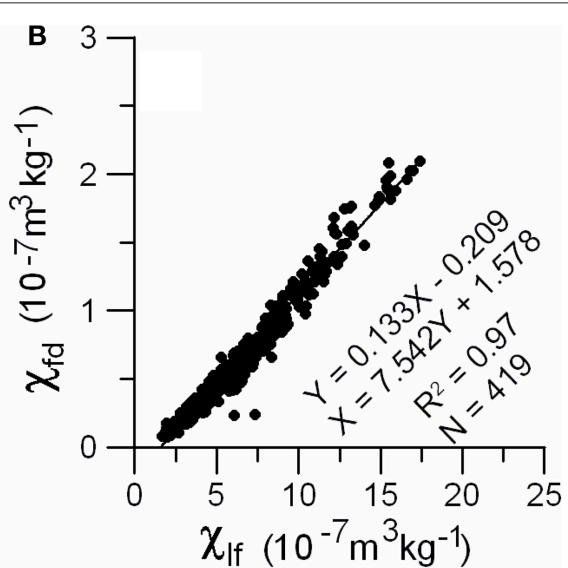

D

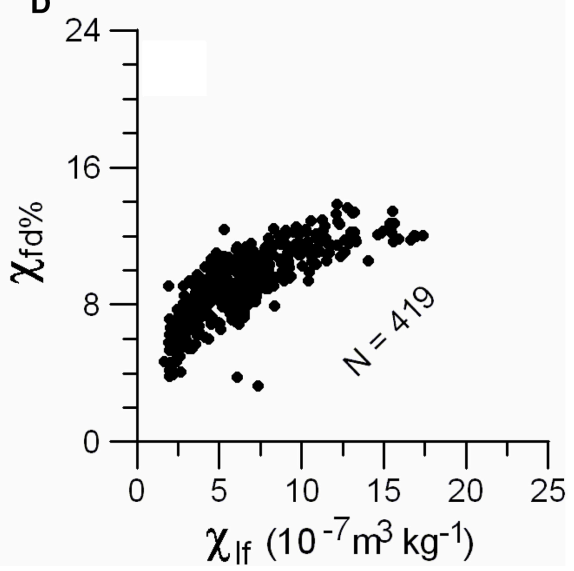

FIGURE 3 | The relationship (Nie et al., 2007) between $\chi_{\text {ARM }}$ vs. $\chi_{f d}(A), \chi_{\text {If }}$ vs. $\chi_{f d}(B), \chi_{\text {If }}$ vs. $\chi_{A R M}$ (C), and $\chi_{f d}$ vs. $\chi_{f d} \%$ (D) in the lower section of the Chinese loess-paleosol sequence from Chaona. $\chi_{f d} \%=\left(\chi_{470 \mathrm{~Hz}}-\chi_{470 \mathrm{~Hz}}\right) / \chi_{470 \mathrm{~Hz}} \times 100$. Modified from Nie et al. (2007). 

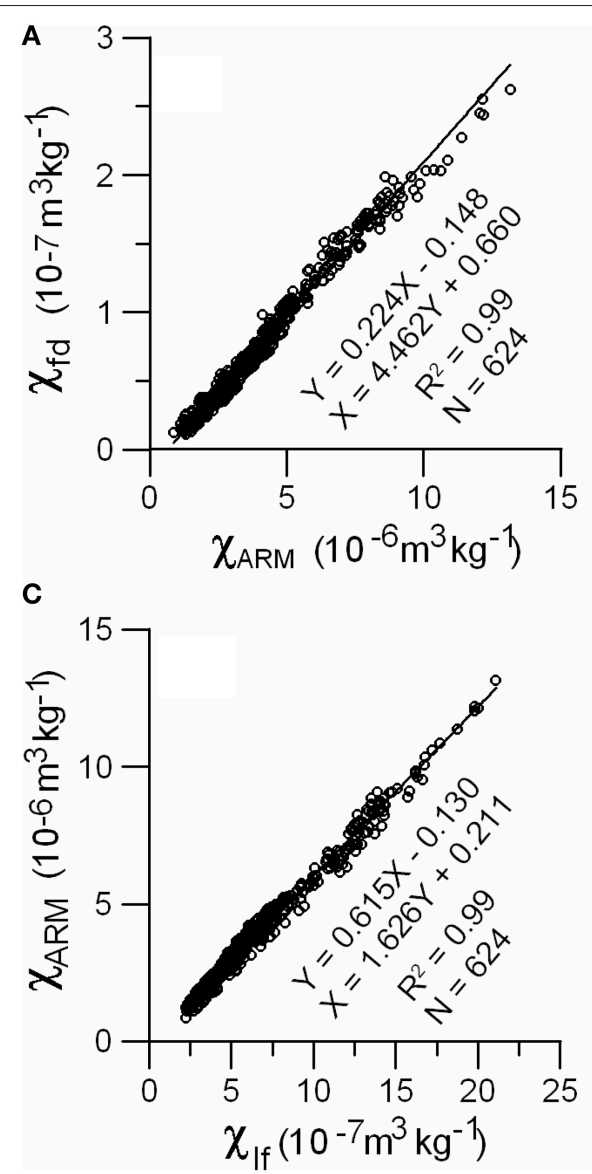

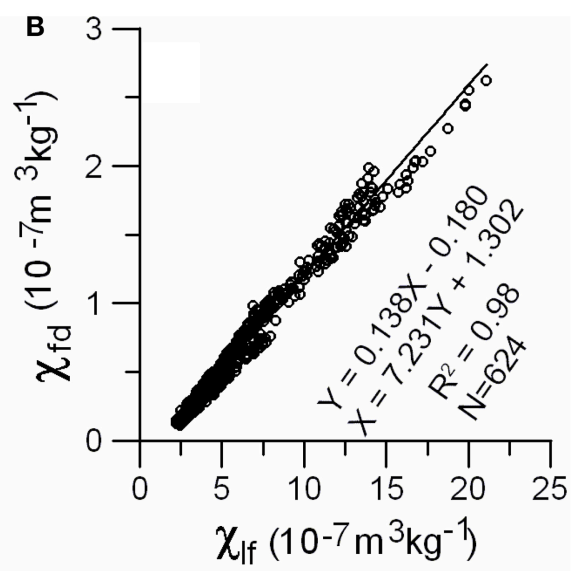

D

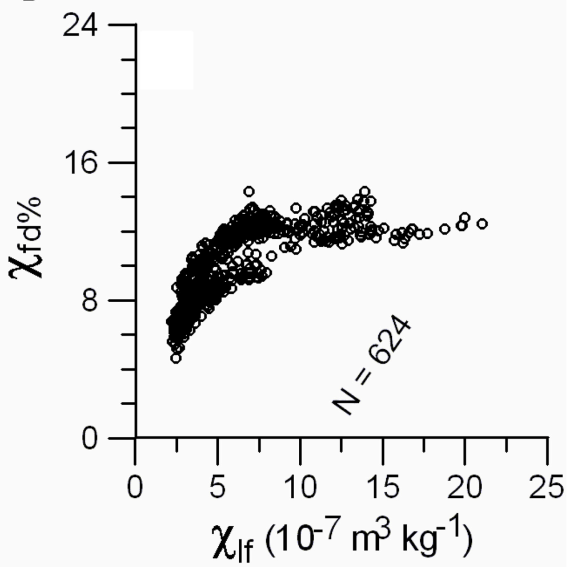

FIGURE 4 | The relationship (Nie et al., 2007) between $\chi_{\text {ARM }}$ vs. $\chi_{f d}(A), \chi_{\text {If }}$ vs. $\chi_{f d}(B), \chi_{\text {If }}$ vs. $\chi_{\text {ARM }}(C)$, and $\chi_{f d}$ vs. $\chi_{f d} \%$ (D) in the red-clay sequence from Chaona. Modified from Nie et al. (2007).

In contrast to their work, Liu et al. (2003) argue that $\chi$ for the red-clay interval can be used to reflect the intensity of the EASM based on linear correlation between $\chi$ and the concentration of superparamagnetic ferrimagnet materials produced by soilformation processes. In addition, $\chi$ is positively correlated to the $\mathrm{Rb} / \mathrm{Sr}$ ratio, an independent proxy for soil weathering intensity associated with rainfall amount (An et al., 2001). Sr and Rb reside in more soluble and more resistant minerals, respectively, and thus soils experiencing stronger weathering will have a higher $\mathrm{Rb} / \mathrm{Sr}$ ratio and vice versa (Chen and An, 1999). Therefore, this correlation also supports the view that $\chi$ is a valid proxy for rainfall variations from the EASM for the red-clay interval. Liu et al. (2003) also found that $\chi_{0}$ (represents the $\chi$ value of parent material; defined as the $\chi$ value when $\chi_{\mathrm{fd}}=0$, where $\chi_{\mathrm{fd}}$ represents frequency dependent susceptibility and is defined as the difference in $\chi$ measured at $470 \mathrm{~Hz}$ and $4700 \mathrm{~Hz}$ ) for loess is $2.1 \times 10^{-7} \mathrm{~m}^{3} \mathrm{~kg}^{-1}$, whereas $\chi_{0}$ for the red-clay is $0.95 \times 10^{-7} \mathrm{~m}^{3} \mathrm{~kg}^{-1}$. This difference may indicate that the redclay sequence and the loess-paleosol sequence might come from different sources. Liu et al. (2003) concluded that more work needs to be done to figure out the linking mechanisms between red-clay $\chi$ and climate.
Building on progress made by previous workers, we have done systematic rock magnetic work on the Chaona redclay sequence on the CLP (Figure 1). We found that the ferrimagnetic grains responsible for enhancement of $\chi$ in the red-clay sequence and the loess sequence have a consistent grain size distribution (Nie et al., 2007, 2008d, 2013a). We found that $\chi$ is positively correlated with $\chi_{\mathrm{fd}}$ and $\chi_{\mathrm{ARM}}$ (anhysteretic susceptibility), indicating that enhancement of $\chi$ is controlled both by the content of superparamagnetic ferrimagnetic grains and single-domain (SD) and pseudo-SD ferrimagnetic grains (Figures 3, 4). In contrast to the work of Liu et al. (2003), we found that the $\chi_{0}$ values for loess deposited between 2.7 and 1.2 $\mathrm{Ma}\left(1.57 \times 10^{-7} \mathrm{~m}^{3} \mathrm{~kg}^{-1}\right)$ and red-clay $\left(1.3 \times 10^{-7} \mathrm{~m}^{3} \mathrm{~kg}^{-1}\right)$ are quite similar (Figures 3, 4). This difference is probably caused by the fact that Liu et al. (2003) use the entire loess sequence but we only use the sequence between 2.7 and 1.2 Ma. Surprisingly, even for samples during $\sim 5-4 \mathrm{Ma}$, the interval during which Ding et al. (1999) suspect that gleying has partially or totally dissolved the ultrafine ferrimagnetic grains responsible for the enhancement of $\chi$, we found that the grain size of ultrafine ferrimagnetic grains are consistent with those from the other intervals (Figures 3-5). This consistent grain size is hard to 

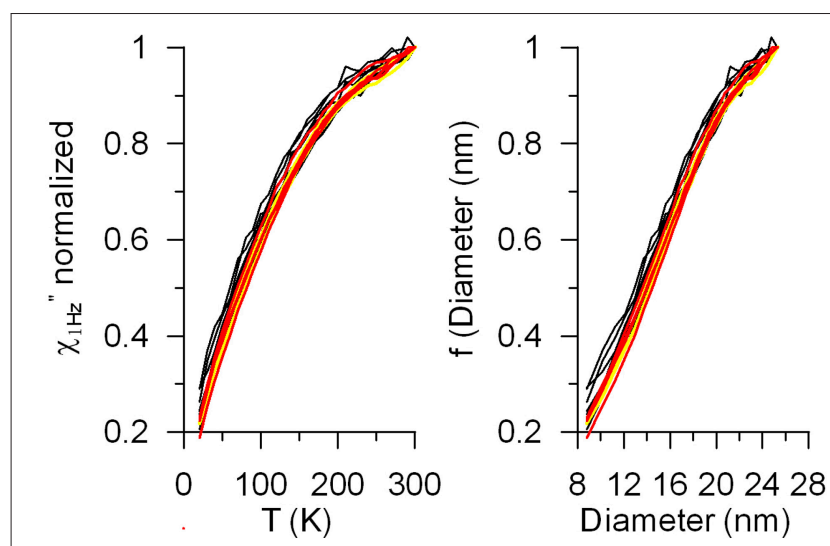

FIGURE 5 | Out-of-phase susceptibility at $1 \mathrm{~Hz}$ vs. temperature $\left(\chi_{1 \mathrm{~Hz}}^{\prime \prime}(\mathrm{T})\right)$ (left) and grain size distribution (right) estimated from $\chi_{1 \mathrm{~Hz}}^{\prime \prime}(\mathrm{T})$ for loess-paleosol samples (yellow), red-clay samples during the interval 4.8-4.1 Ma (black), and red-clay samples outside the interval 4.8-4.1 Ma (red). The grain size distribution of ferrimagnetic minerals (presumably maghemite) is consistent for all samples (Nie et al., 2008d).

understand if reductive dissolution has occurred because such dissolution will tend to remove smaller grains more readily than larger grains and thus the grain size distribution should have been changed. The observation that the grain size distributions for the red-clay sequence and the loess sequence are consistent suggests that reductive dissolution might not have been a significant factor for causing lower $\chi$ for the interval $\sim 5-4 \mathrm{Ma}$.

In order to find an alternative explanation for the lower $\chi$ values for red-clay deposited between 5 and $4 \mathrm{Ma}$, we have compared the $\chi$ record from Chaona with the benthic oxygen isotope record from the Eastern Equatorial Pacific Ocean (Shackleton et al., 1990, 1995; Figure 6). We found that $\chi$ has a negative correlation with the benthic oxygen isotope record from 6 to $4.5 \mathrm{Ma}$, indicating that monsoon precipitation was higher when ice volume was smaller and/or climate was warmer (Figure 6). This relationship is readily understandable because model simulations demonstrate that the summer monsoon would be stronger in a warmer climate. Therefore, the lower $\chi$ values between 5 and $4.5 \mathrm{Ma}$ in the red-clay sequence can be explained by colder climate and/or larger ice volume. We argue that these changes provide a more plausible explanation for the low values of $\chi$ at that time period and that the higher content of clay coats and Fe-Mn films might be caused by factors other than monsoon rainfall, such as the time of soil formation (Nie et al., 2013b). Maher and $\mathrm{Hu}$ (2006) have demonstrated that the magnetic enhancement of Chinese loess is mainly controlled by monsoon precipitation intensity and is not related to the time of soil formation based on age constraints from OSL dating. For this reason, we suggest that $\chi$ is a better proxy for the intensity of the EASM than field observations of soil characteristics.

Correlation between the $\chi$ record and the benthic oxygen isotope record during the last $6 \mathrm{Myr}$ also reveals other important paleoclimatic information. We found a good correlation between the $\chi$ record and the benthic oxygen isotope record during
TABLE 1 | Magnetic hyperfine parameters of the red-clay sample CN 4940, CN4360, and CN12000.

\begin{tabular}{|c|c|c|c|c|c|c|}
\hline Sample & $\mathbf{T}(\mathrm{K})$ & $\mathrm{B}_{\mathrm{HF}}(\mathrm{T})$ & QS (mm/s) & IS (mm/s) & $\%$ & Iron phase \\
\hline \multirow{7}{*}{$\begin{array}{l}\text { CN4940 } \\
(4.73 \mathrm{Ma})\end{array}$} & 4.2 & 53.1 & -0.16 & 0.53 & 29 & Hematite \\
\hline & & 50.6 & -0.16 & 0.50 & 15 & Goethite \\
\hline & & - & 0.81 & 0.47 & 47 & $\mathrm{Fe}^{3+}$ \\
\hline & & - & 2.33 & 1.54 & 9 & $\mathrm{Fe}^{2+}$ \\
\hline & 300 & 51.0 & -0.20 & 0.42 & 11 & Hematite \\
\hline & & - & 0.71 & 0.34 & 77 & $\mathrm{Fe}^{3+}$ \\
\hline & & - & 2.29 & 1.32 & 12 & $\mathrm{Fe}^{2+}$ \\
\hline \multirow{3}{*}{$\begin{array}{l}\text { CN4360 } \\
(4.28 \mathrm{Ma})\end{array}$} & 300 & 50.6 & -0.20 & 0.41 & 11 & Hematite \\
\hline & & - & 0.71 & 0.36 & 80 & $\mathrm{Fe}^{3+}$ \\
\hline & & - & 2.25 & 1.35 & 9 & $\mathrm{Fe}^{2+}$ \\
\hline \multirow{3}{*}{$\begin{array}{l}\text { CN12000 } \\
(7.81 \mathrm{Ma})\end{array}$} & 300 & 51.0 & -0.18 & 0.38 & 14 & Hematite \\
\hline & & - & 0.81 & 0.31 & 66 & $\mathrm{Fe}^{3+}$ \\
\hline & & - & 2.32 & 1.29 & 20 & $\mathrm{Fe}^{2+}$ \\
\hline
\end{tabular}

Revised from Nie et al. (2010).

Maximum hyperfine field-BHF, isomer shift-IS, quadrupole splitting-QS and relative proportions of iron components-\%.

the last $6 \mathrm{Myr}$ except for the interval between 4.5-2.7 Ma (Figure 6). For this interval, $\chi$ is higher when the benthic oxygen isotope ratio is higher. We have attributed this lack of correlation between these two records during this interval to closure of the Panama Seaway and/or uplift of the Tibetan Plateau (Nie et al., 2008a,b, 2014b). Model simulations support that either factor can increase rainfall on the CLP and thereby overcome decreases in rainfall caused by increased ice volume and colder climate (An et al., 2001; Motoi and Chan, 2010). However, which factors are more important needs to be studied further.

The red-clay sequence has a lower sedimentation rate in comparison with that of the loess-paleosol sequence. Due to lower sedimentation rates and increased bioturbation and post-depositional smoothing effects, shorter-period orbital signals, such as obliquity and precession signals have been largely smoothed, which makes the red-clay sequence ideal for studying eccentricity signals (Nie et al., 2008c). Nie et al. (2008c) found that the 400-kyr eccentricity signal intensified at around $4 \mathrm{Ma}$ in the red-clay sequence. This intensification is synchronous with intensification of the 400-kyr signal in ice volume records (Clemens and Tiedemann, 1997). Nie et al. (2008c) proposed that the EASM system and ice volume probably crossed a precipitation amount threshold and a low temperature threshold, respectively. Crossing of these thresholds by the two systems may have resulted in a clipped response to insolation forcing. Thus, 400-kyr signals became intensified in these two types of sedimentary record. Nie et al. (2008c) hypothesize that accelerated uplift of the Tibetan Plateau is the required forcing for pushing these two systems to cross these two thresholds at $\sim 4 \mathrm{Ma}$. 


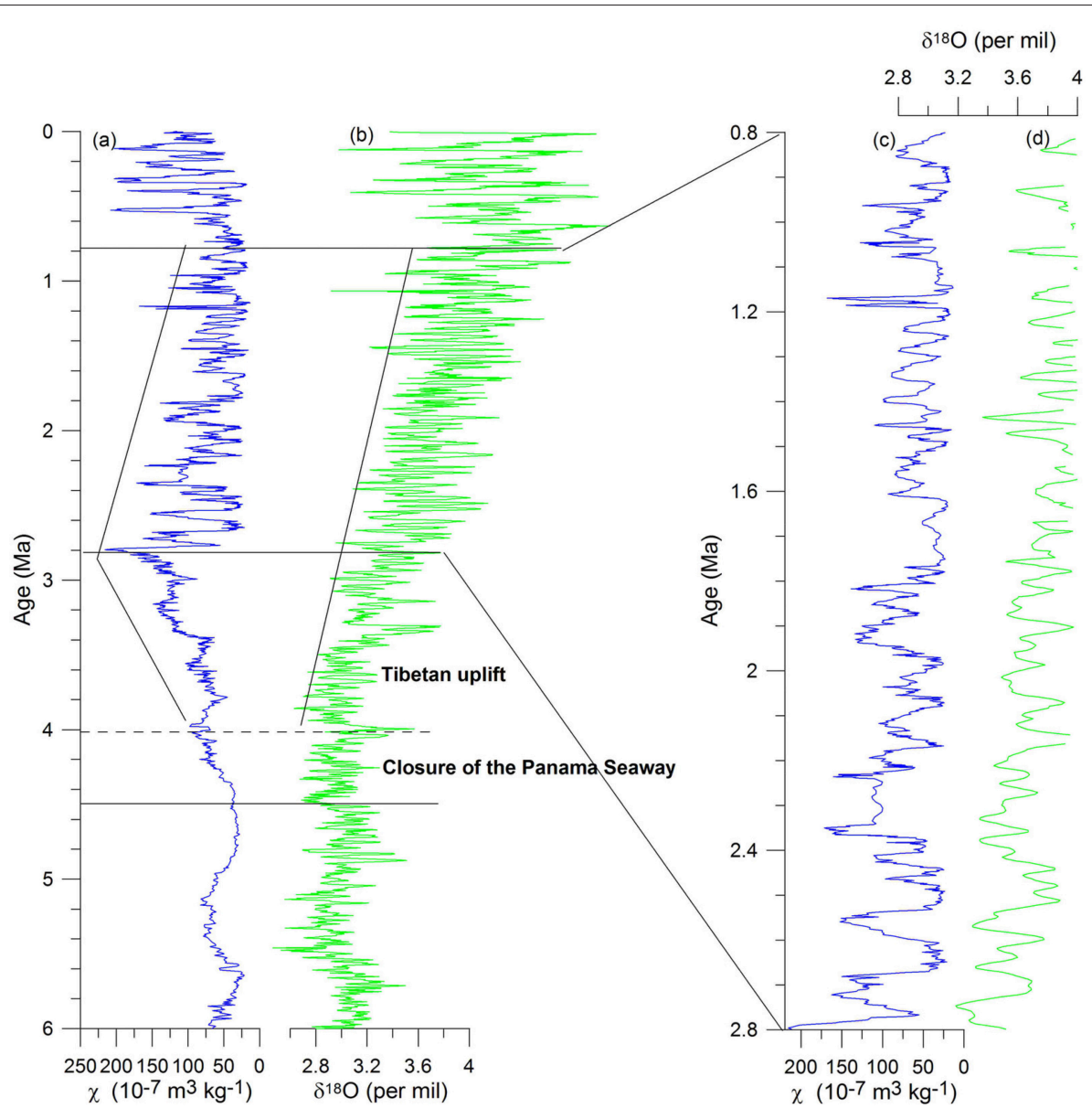

FIGURE 6 | Comparison between benthic oxygen isotope record $\left(\delta^{18} \mathrm{O}\right)$ from the eastern Equatorial Pacific Ocean (Shackleton et al., 1990, 1995) and the $x$ record from the CLP during the last 6 Ma showing possible effects of ice volume and tectonic events to the EASM. (A) The $\chi$ record from Chaona between 6-0 Ma. The age model of the interval 2.8-0 Ma is based on orbital tuning (Heslop et al., 2000; Lü et al., 2001) and the age model of the interval 6-2.8 Ma is based on magnetostratigraphy (Song et al., 2001). (B) The benthic $\delta^{18} \mathrm{O}$ record between 6-0 Ma. (C) Is the 2.8-0.8 Ma portion of (A). (D) Is the 2.8-0.8 Ma portion of smoothed (B) with values greater than 4 per mil clipped. In comparison with (A) and (B), improved correlation between (C) and (D) is obvious. Modified from Nie et al. (2008a).

In addition to the 400-kyr cycles, Nie (2011) also examined the 100-kyr cycles in the $\chi$ record from the CLP and in the benthic oxygen and carbon isotope records during the last $5 \mathrm{Myr}$. The results show that these three records are phase-locked and amplitude-coupled at the 100-kyr band between 3 and $1 \mathrm{Ma}$, but none of them are phase-locked to and amplitude-coupled with the 100-kyr eccentricity signal (Figure 7). These results suggest a free 100-kyr oscillation as the cause of the 100-kyr band amplitude variability in paleoclimatic records before $1 \mathrm{Ma}(\mathrm{Nie}$, 2011).

In summary, the $\chi$ record from the CLP has good correlation with the benthic oxygen isotope record during the last $6 \mathrm{Myr}$ except during $\sim 4.5-2.7 \mathrm{Ma}$. The good correlation indicates ice volume forcing of the EASM as early as $6 \mathrm{Ma}$ and the lack of correlation during $\sim 4.5-2.7 \mathrm{Ma}$ can be attributed to tectonic forcing of the EASM. In contrast to previous studies questioning the validity of $\chi$ as an indicator for intensity of the EASM in the red-clay sequence, we argue that $\chi$ is a valid proxy for the intensity of the EASM during 6-2.7 Ma. This proxy is valid because, like in the loess-paleosol sequence, enhancement of $\chi$ in the red-clay sequence is also caused by the concentration increase of superparamagnetic (SP), stable-single domain (SSD), and smaller pseudo-single domain (PSD) ferrimagnetic grains, which have quite similar grain size distribution patterns.

\section{PALEOCLIMATE HISTORY OF THE CHINESE LOESS PLATEAU RECORDED BY RED-CLAY MAGNETIC GRAIN SIZE PARAMETERS}

Pedogenesis produces large amounts of fine SSD and small PSD magnetic grains having high anhysteretic susceptibility ( $\chi_{\mathrm{ARM}}$ ) but low $\chi_{\text {LF }}$ during soil formation (Liu et al., 2007). Interparameter proxies for magnetic grain-size variations, such as $\chi_{\text {ARM }} / \chi_{\text {LF }}$ and $\chi_{\text {ARM }} / S I R M$, where SIRM represents saturated 


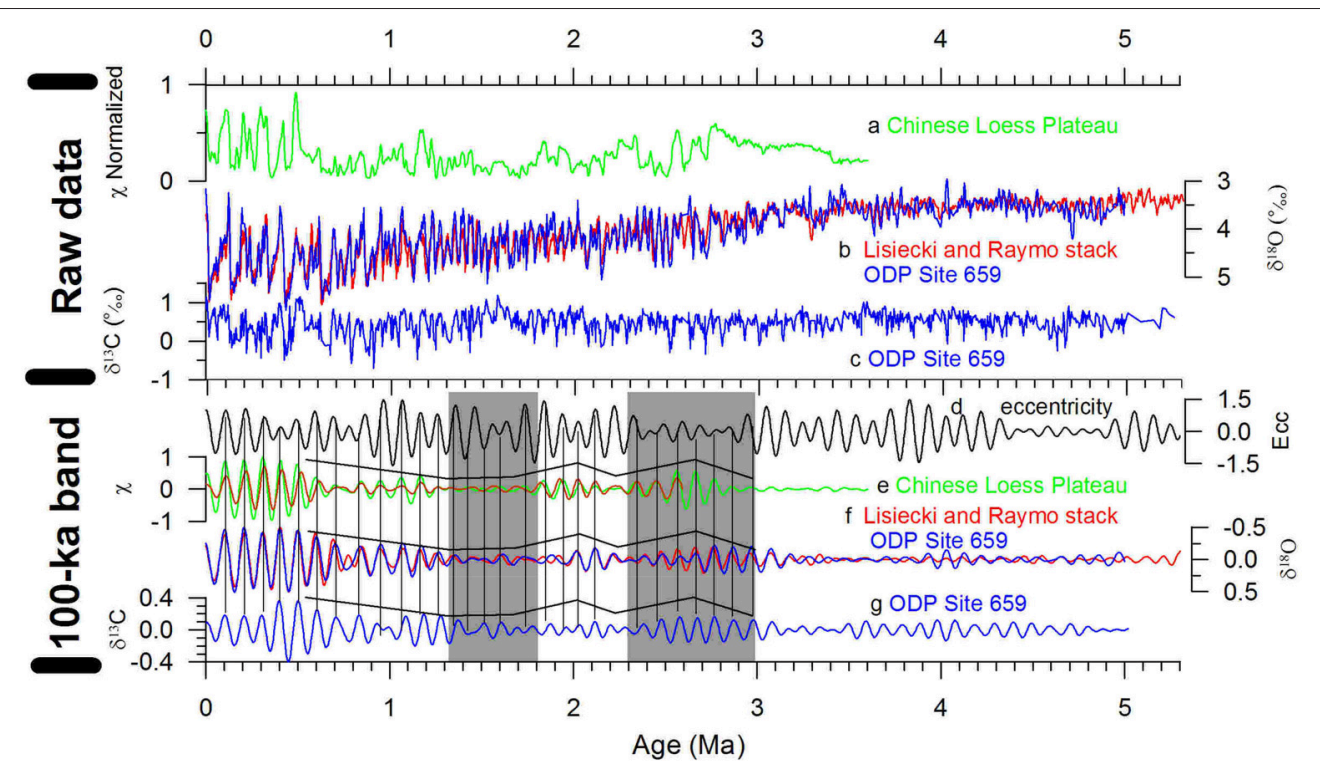

FIGURE 7 | Paleoclimate time series and the 100-kyr band variability associated with each record (Nie, 2011). (A) The $\chi$ stack record of Sun et al. (2006) from the CLP. (B) Benthic $\delta^{18} \mathrm{O}$ record from ODP Site 659 (blue) and benthic $\delta^{18} \mathrm{O}$ stack record synthesized by Lisiecki and Raymo (2005) (red). (C) Benthic $\delta^{13} \mathrm{C}$ time series from ODP Site 659. Benthic $\delta^{13} \mathrm{C}$ is generally used as a proxy for paleo-ocean circulation change/global carbon mass balance (Tiedemann et al., 1994; Piotrowski et al., 2005). (D) The filtered 100-kyr band variability of Earth's orbital eccentricity (Laskar, 1990). (E-G) The filtered 100-kyr band of variability of (A-C), respectively. In (E) the filtered 100-kyr band of variability of the Chaona $x$ record is also shown for comparison (brown). Note that there is weak forcing but strong response from 3 to $2.3 \mathrm{Ma}$ (the shaded bar), and strong forcing but weak response from 1.8 to $1.3 \mathrm{Ma}$ (the shaded bar). The trend lines in (E-G) indicate coupled amplitude variation in these three data sets.

isothermal remanent magnetization and measures the magnetic grain concentration with remanence, are thus climate controlled (King and Channell, 1991; Verosub and Roberts, 1995). Recently, Nie et al. (2014b) calibrated $\chi_{\text {ARM }} / \chi_{\text {LF }}$ and $\chi_{\text {ARM }} / S I R M$ with annual mean temperature (AMT) and precipitation (AMP) using surface soil samples collected from across the CLP and then used these calibration results as a guide to explain $\chi_{\mathrm{ARM}} / \chi_{\mathrm{LF}}$ and $\chi_{\text {ARM }} /$ SIRM variations of the red-clay sequence on the CLP.

They found that $\chi_{\text {ARM }} / S I R M$ and $\chi_{\text {ARM }} / \chi_{\text {LF }}$ are extremely sensitive to high precipitation and low temperature variation, respectively (Figure 8). Magnetic parameter values of the eolian component for Chinese loess are roughly constant as seen from the limited change in the rock magnetic properties of the loess units on the CLP over time (Verosub and Roberts, 1995; An et al., 2001; Bloemendal and Liu, 2005). For this reason, the correlation between $\chi_{\mathrm{ARM}} / \chi_{\mathrm{LF}}$ and temperature suggests that the relative proportion of fine magnetic grains with remanence vs. ultrafine magnetic grains without remanence is temperature dependent, whereby lower temperature and colder climate tend to produce more ultrafine grains relative to fine grains.

However, these surface calibrations can be best used as guides to understand the paleoclimatic implications of the magnetic parameters and quantitative AMT and AMP estimates will have large uncertainties. In paleoclimate records, if $\chi_{\text {ARM }} / \chi_{\text {LF }}$ and $\chi_{\text {ARM }} / S I R M$ co-vary with each other, it indicates that temperature and precipitation on the CLP are coupled (i.e., higher precipitation accompanies higher temperature or lower precipitation accompanies lower temperature). However, if different trends are observed between $\chi_{A R M} / \chi_{L F}$ and $\chi_{\text {ARM }} / S I R M$ records, it indicates that $\chi_{\text {ARM }} / \chi_{\text {LF }}$ reflects mainly temperature variations, especially during colder climate periods. Using this observation as a guide, we were able to recognize that, during the interval 4.5-2.7 Ma, the CLP experiences a cooling trend, while the monsoon precipitation was increasing. This interpretation is consistent with the results based on $\chi_{\mathrm{LF}}$.

Summer monsoon intensity results presented here are not consistent with the free iron/total iron ratio variations, and soil development features (Ding et al., 2001b), which indicate that the East Asian summer monsoon was stronger during the early Pliocene. We argue that these proxies are more useful for inferring the paleo-summer monsoon intensity history when temperature and precipitation variations are in phase, but that caution is required for intervals when temperature and precipitation variations are out of phase, for example the interval between 4.5 and $2.7 \mathrm{Ma}$ (Figure 9). This magnetic study provides a potential way to recognize intervals when temperature and precipitation were out of phase in the geologic past.

\section{COMPARING OTHER MAGNETIC PARAMETERS BETWEEN THE LOESS-PALEOSOL SEQUENCE AND THE RED-CLAY SEQUENCE}

Like the loess-paleosol sequence, both low coercivity minerals (magnetite and maghemite), and high coercivity minerals (hematite and goethite) have been inferred to exist in the red-clay sediments (Liu et al., 1995; Song et al., 2007; Hao 

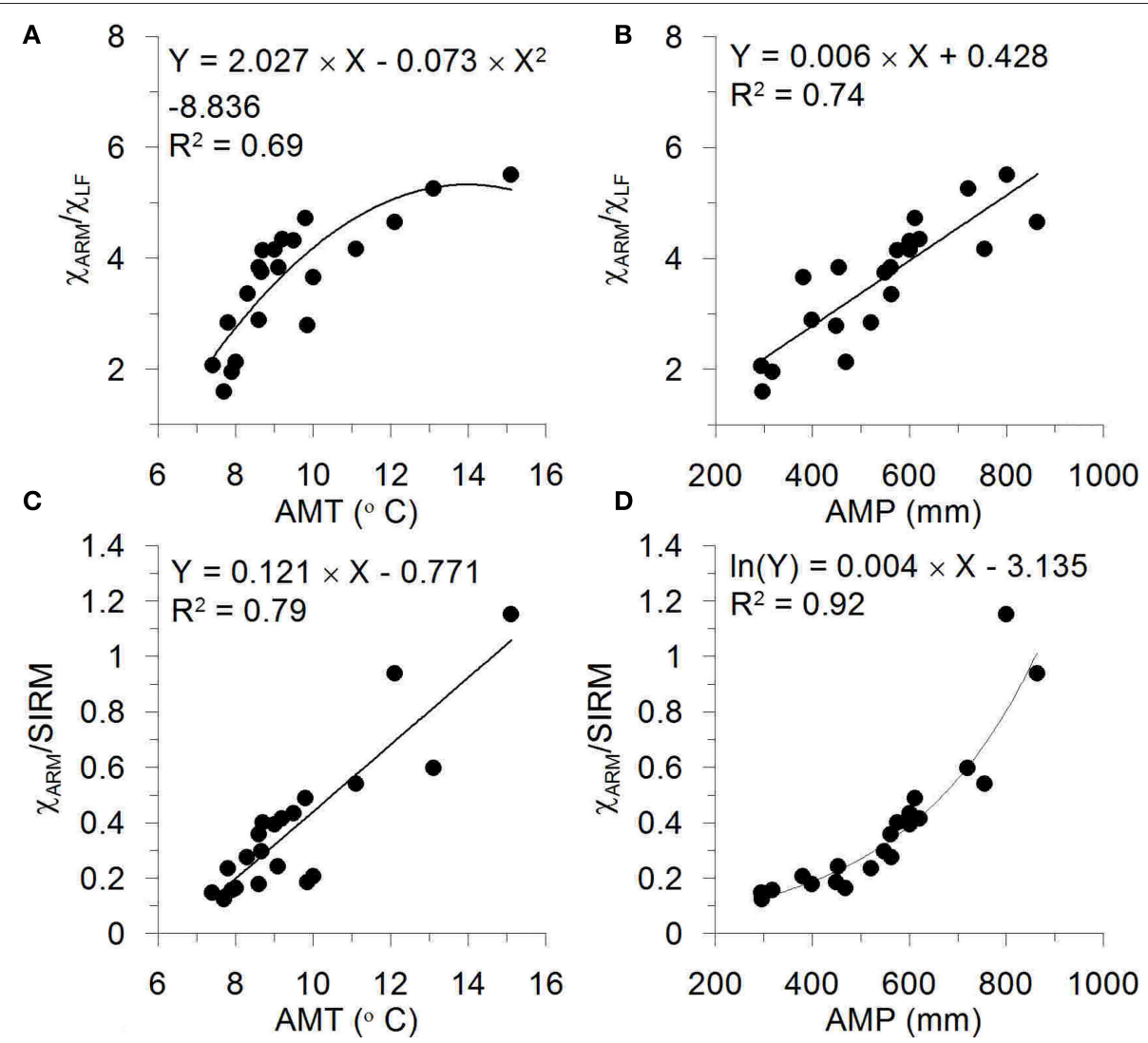

FIGURE 8 | Correlation patterns between Chinese Loess Plateau surface soil magnetic and climatic parameters. Modified from Nie et al. (2014b). (A), $\chi_{A R M} / \chi_{L F}$ and annual mean temperature (AMT); (B), $\chi_{A R M} / \chi_{L F}$ and annual mean precipitation (AMP); (C), $\chi_{A R M} / S I R M$ and AMT; (D), $\chi_{A R M} / S I R M$ and AMP.

et al., 2009; Nie et al., 2010). However, Mössbauer spectra data show that although goethite comprises about $15 \%$ of all iron-bearing minerals, they are in the SP range and have no remanence at room temperature (Table 1). In contrast, hematite has both a SP component and coarser components that have stable remanence at room temperature (Table 1). Obviously, magnetite and maghemite in the red-clay sediments comprise a tiny proportion of all iron-bearing minerals, and they can not be detected by Mössbauer measurements.

Nie et al. (2010) also examined hematite content variations recorded by the red-clay sequence. Using "hard" isothermal remanent magnetization (HIRM) as a proxy for hematite content (King and Channell, 1991; Bloemendal and Liu, 2005), they found that although the red-clay sequence has a redder color in comparison with the overlying loess-paleosol sequence, hematite content in the red-clay sequence is instead lower (Nie et al., 2010). This apparent contradiction might come from the proxy that they used to reflect hematite content. Although, their Mössbauer spectra data suggest that goethite does not contribute to HIRM at room temperature, HIRM is a remanence and thus does not reflect the hematite content comprised of SP grains, which are most likely produced via pedogenesis and are responsible for the redder color of the red-clay sequence. Nie et al. (2010) also noticed that, during 8-3.5 Ma and 2.6-1 Ma, HIRM has a positive relationship with $\chi_{\mathrm{fd}}$, and during 3.5-2.6 Ma, these parameters have a negative relationship. Nie et al. (2010) argue that the positive relationship between HIRM and $\chi_{\mathrm{fd}}$ requires that the hematite is derived from external source regions instead of being produced in situ by pedogenesis. Hematite favors dryer and hotter climate, whereas ultrafine ferrimagnetic grains produced by pedogenesis require wetter climate. Thus, if hematite was produced in-situ during pedogenesis on the CLP, it is hard to understand the co-occurrence of a higher abundance of hematite and ultrafine ferrimagnetic grains. However, in desert source regions, the climate is dry and hot, which is very suitable for hematite formation. It is reasonable to attribute hematite reflected by HIRM to eolian transport from desert the source regions. Following this logic, HIRM might be a useful proxy for paleo-temperature in the source regions. If this hypothesis is valid, then HIRM may be a very useful high-resolution proxy for reconstructing paleoclimate in the dust source regions during the last 8 or $6 \mathrm{Ma}$ because in comparison with the $\chi_{\mathrm{fd}}$ data, HIRM includes higher-frequency orbital signals. The higherfidelity recording by HIRM may indicate that hematite grains are not sensitive to post-depositional alteration, in contrast to magnetic grains reflected by $\chi_{\mathrm{fd}}$ (Nie et al., 2010). Nie et al. (2010) argue that the negative relationship between HIRM and $\chi_{\mathrm{fd}}$ indicates that the wetter climate during this period might have 


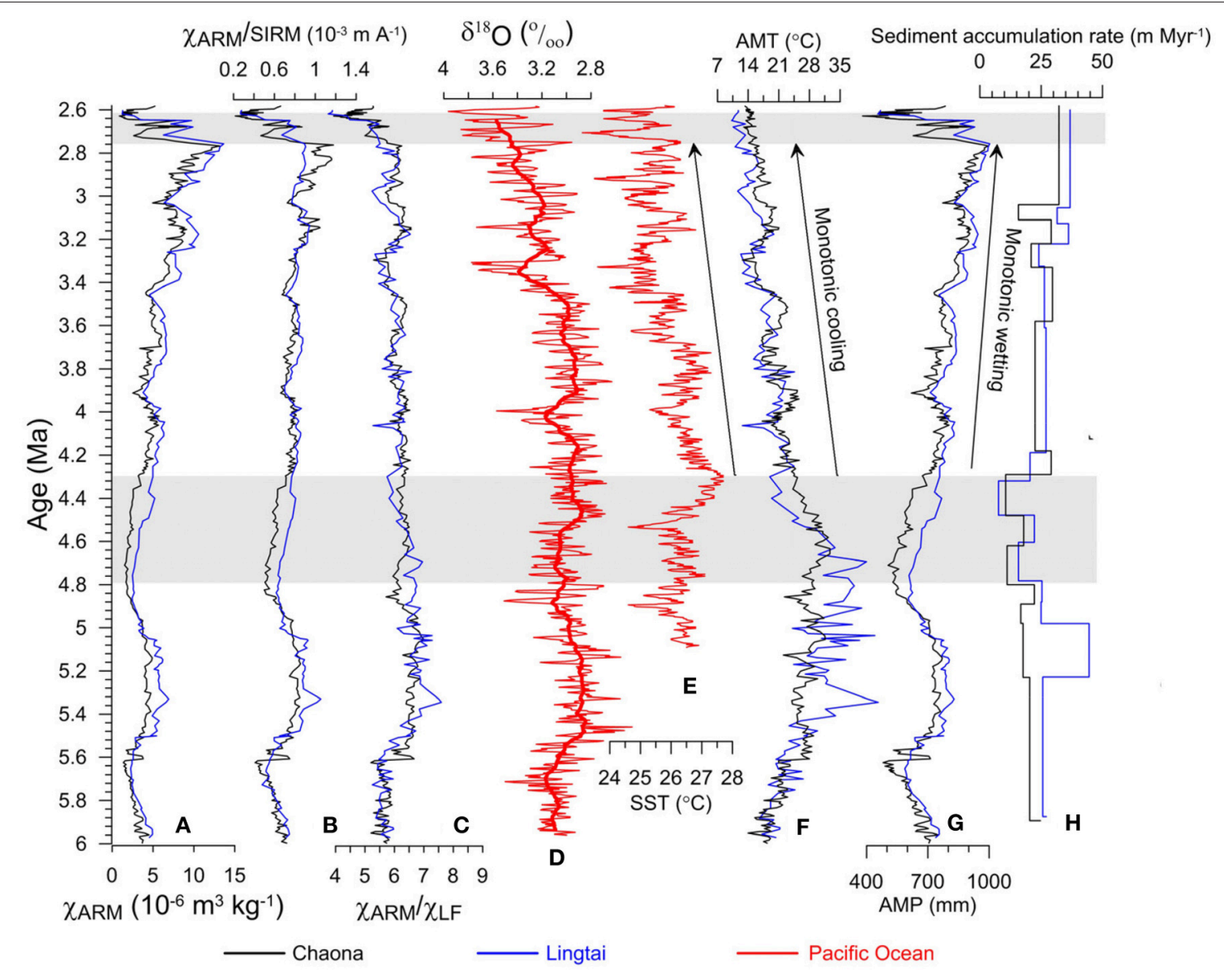

FIGURE 9 | Paleoclimatic and paleoceanographic data for the time interval 6-2.6 Ma. Modified from Nie et al. (2014b). (A-C) The Chaona (black) and Lingtai (blue) $\chi_{A R M}, \chi_{A R M} / S I R M$ and $x_{A R M} / \chi_{L F}$ records, respectively. (D,E) East Equatorial Pacific Ocean Drilling Project (ODP) site 846 benthic oxygen isotope (Shackleton et al., 1995) and sea surface temperature (Lawrence et al., 2006) records respectively. (F,G) Reconstructed Chaona (black) and Lingtai (blue) annual mean temperature (AMT) and annual mean precipitation (AMP) records. (H) Chaona (black) and Lingtai (blue) sedimentation rate records.

changed hematite to magnetite. This hypothesis needs further rock magnetic work to confirm.

Nie et al. (2014c) recently performed backfield remanence curve unmixing on loess and red-clay using the method developed by Heslop and Dillon (2007), which does not require pre-defined end members. The results reveal that backfield curves of both loess and red-clay can be unmixed as two end members (Figure 10). For loess-paleosol and red-clay samples, the two end members have coercivity peaks at 21 and $72 \mathrm{mT}$, and 21 and $32 \mathrm{mT}$, respectively. The abundance of the end member with the peak at $21 \mathrm{mT}$ for both loess-paleosol and red-clay samples covaries with $\chi_{L F}$, indicating its pedogenic origin. The fact that both loess-paleosol and red-clay have a similar pedogenic component confirms that they have a similar magnetic enhancement mechanism. Nie et al. (2014c) attribute the end member with a peak at $72 \mathrm{mT}$ for loesspaleosol samples to weak oxidation of detrital magnetite resulting in a magnetite core with a maghemite rim. By contrast, the end member with a peak at $32 \mathrm{mT}$ for red-clay samples was attributed to a high degree of oxidation of detrital magnetite grains, which suppresses the coercivity contrast between the magnetite core and the maghemite rim, resulting in decreased coercivity. This explanation is consistent with a colder climate after 2.7 Ma, which tends to produce weak oxidation. Nie et al. (2014c) also observed that the abundance of the end member with a coercivity peak at $32 \mathrm{mT}$ decreased from the early to late Pliocene and they attributes this decrease to climatic cooling, consistent with the intensification of the Northern Hemisphere glaciations during the late Pliocene. In addition to these two ferrimagnetic end members, a third end member with a coercivity peak at $330 \mathrm{mT}$ is also detected from the loess-paleosol and red-clay samples, which should correspond to pedogenic hematite.

In summary, although the loess-paleosol sequence and the underlying red-clay sequence have similar magnetic mineralogy including magnetite, maghemite, hematite, and goethite, a striking difference between these two sequences is that magnetic minerals in the red-clay sequence experienced a higher degree of oxidation, corresponding to the warmer temperature during the late Miocene-Pliocene. This observation provides a 

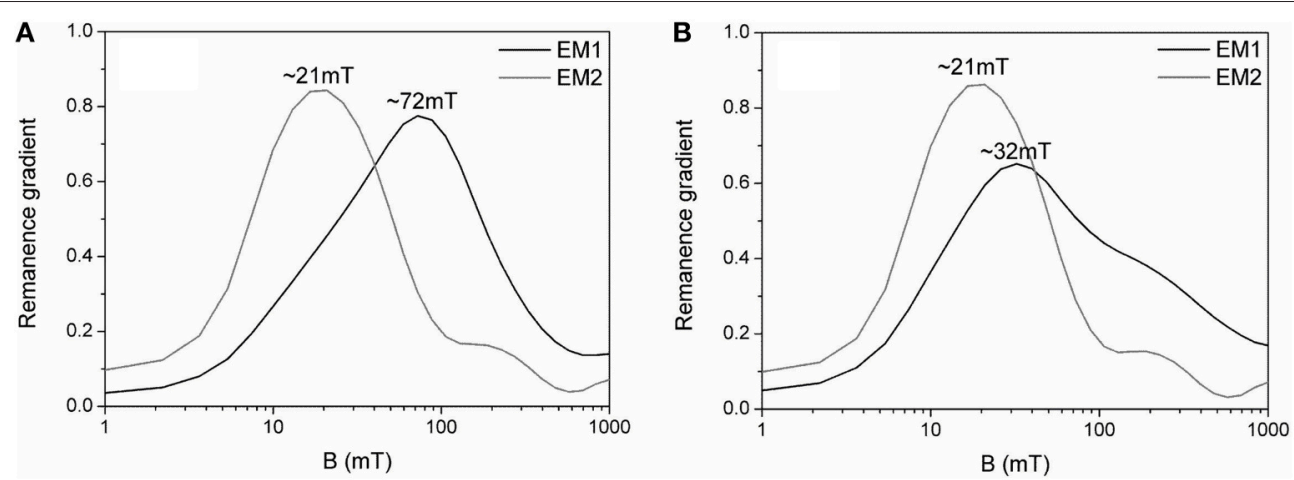

FIGURE 10 | A comparison end members (EMs) of backfield IRM curve unmixing of the Chaona (A) loess-paleosol and (B) red-clay samples. Modified from Nie et al. (2014C).

potential approach for using magnetic parameters to infer the paleotemperature history on the CLP.

\section{FUTURE RESEARCH DIRECTIONS}

It is clear from this review that future red-clay environmental magnetic work needs to emphasize understanding magnetic mineral transfer routes in order to make rock magnetic parameters more useful for extracting paleoclimate information from this eolian sequence. In order to understand magnetic mineral transfer routes, one has to obtain a clear understanding of (1) how the concentration of high-coercivity minerals, like goethite and hematite, varied during 6-2.7 Ma and (2) what is the relationship between the concentration of highcoercivity minerals and low-coercivity minerals in the redclay sequence. It is clear that enhancement of $\chi$ both in the loess-paleosol and in the red-clay sequence is caused by an increase in the concentration of $<100 \mathrm{~nm}$ magnetite or maghemite grains, However, if weakly magnetic minerals convert to both hematite and magnetite in part of the redclay sequence, whereas they primarily convert to magnetite and are later oxidized to maghemite in the other parts of the sequence, then we need to determine what climatic conditions promote the different mineral transfer routes. This determination is critical to understanding the history of the EASM. In contrast to strongly magnetic minerals, much is unknown about

\section{REFERENCES}

Alonso-Zarza, A. M., Zhao, Z., Song, C. H., Li, J. J., Zhang, J., MartinPerez, A., et al. (2009). Mudflat/distal fan and shallow lake sedimentation (upper Vallesian-Turolian) in the Tianshui Basin, Central China: evidence against the late Miocene eolian loess. Sediment. Geol. 222, 42-51. doi: 10.1016/j.sedgeo.2009.03.010

An, Z. S., Kutzbach, J. E., Prell, W. L., and Porter, S. C. (2001). Evolution of Asian monsoons and phased uplift of the Himalaya-Tibetan plateau since Late Miocene times. Nature 411, 62-66. doi: 10.1038/35075035

Andersson, J. G. (1923). Essays on the Cenozoic of Northern China. Geol. Surveys China. Memoirs Ser. A 3, 107-114. concentration variations and the formation mechanisms and magnetic transform routes of the weakly magnetic minerals hematite and goethite in the red-clay sequence. Two contrasting formation mechanisms of hematite have been proposed. The classic viewpoint (Schwertmann and Taylor, 1989) argues that the hematite forms by dehydrating ferrihydrites and thus high temperature and dry climate favor formation of hematite. on the other hand, some authors propose that the production of hematite results from the aging of maghemite grains that are in turn produced by the aging of ferrihydrites (Torrent et al., 2006; Liu et al., 2008, 2012; Long et al., 2015). Therefore, future studies need to continue to focus on clarifying the formation mechanisms of hematite and goethite.

\section{AUTHOR CONTRIBUTIONS}

All authors listed, have made substantial, direct and intellectual contribution to the work, and approved it for publication.

\section{ACKNOWLEDGMENTS}

Comments by two reviewers improved structure and clarity of the paper. This work is co-supported by the (973) National Basic Research Program of China (Grant No. 2013CB956400), the Strategic Priority Research Program of the Chinese Academy of Sciences (Grant No. XDB03020400), the National Natural Science Foundation (Grant Nos. 41422204; 41290253).

Anwar, T., Kravchinsky, V. A., and Zhang, R. (2015). Magneto- and cyclostratigraphy in the red clay sequence: new age model and paleoclimatic implication for the eastern Chinese Loess Plateau. J. Geophys. Res. 120, 6758-6770. doi: 10.1002/2015JB012132

Banerjee, S. K., Hunt, C., and Liu, X. (1993). Separation of local signals from the regional paleomonsoon record of the Chinese loess plateau: a rock-magnetic approach. Geophys. Res. Lett. 20, 843-846. doi: 10.1029/93G L00908

Bloemendal, J. C., and Liu, X. (2005). Rock magnetism and geochemistry of two plio-pleistocene Chinese loess-paleosol sequences-implications for quantitative palaeoprecipitation reconstruction. Palaeogeogr. Palaeoclimatol. Palaeoecol. 226, 149-166. doi: 10.1016/j.palaeo.2005.05.008 
Chen, J., and An, Z. S. (1999). Variation of Rb/Sr Ratios in the LoessPaleosol sequences of Central China during the last 130,000 years and their implications for Monsoon Paleoclimatology. Quat. Res. 51, 215-219. doi: 10.1006/qres.1999.2038

Clemens, S. C., and Tiedemann, R. (1997). Eccentricity forcing of Pliocene-early Pleistocene climate revealed in a marine oxygen-isotope record. Nature 385, 801-804. doi: 10.1038/385801a0

Deng, C., Vidic, N., Verosub, K., Singer, M., Liu, Q., Shaw, J., et al. (2005). Mineral magnetic variation of the Jiaodao Chinese loess/paleosol sequence and its bearing on long-term climatic variability. J. Geophys. Res. 110, B03103. doi: 10.1029/2004jb003451

Ding, Z. L., Sun, J. M., Liu, T. S., Zhu, R. X., Yang, S. L., and Guo, B. (1998). Wind-blown origin of the Pliocene red clay formation in the central Loess Plateau, China. Earth Planet. Sci. Lett. 161, 135-143. doi: 10.1016/S0012821X(98)00145-9

Ding, Z. L., Sun, J. M., Yang, S. L., and Liu, T. S., (2001a). Geochemistry of the Pliocene red clay formation in the Chinese Loess Plateau and implications for its origin, source provenance and paleoclimate change. Geochim. Cosmochim. Acta 65, 901-913. doi: 10.1029/2001GL013290

Ding, Z. L., Xiong, S. F., Sun, J. M., Yang, S. L., Gu, Z. Y., and Liu, T. S. (1999). Pedostratigraphy and paleomagnetism of a $\sim 7.0$ Ma eolian loess-red clay sequence at Lingtai, Loess Plateau, north-central China and the implications for paleomonsoon evolution. Palaeogeogr. Palaeoclimatol. Palaeoecol. 152, 49-66. doi: 10.1016/S0031-0182(99)00034-6

Ding, Z. L., Yang, S. L., Sun, J. M., and Liu, T. S., (2001b). Iron geochemistry of loess and red clay deposits in the Chinese Loess Plateau and implications for long-term Asian monsoon evolution in the last 7.0 Ma. Earth Planet. Sci. Lett. 185, 99-109. doi: 10.1029/2001GL013290

Evans, M. E., and Heller, F. (1994). Magnetic enhancement and paleoclimate: study of a loess/palaeosol couplet across the Loess Plateau. Geophys. J. Int. 117, 257-264. doi: 10.1111/j.1365-246X.1994.tb03316.x

Guo, B., Zhu, R. X., Roberts, A. P., and Florindo, F. (2001). Lack of correlation between paleoprecipitation and magnetic susceptibility of Chinese loess/paleosol sequences. Geophys. Res. Lett. 28, 4259-4262. doi: 10.1029/2001GL013290

Guo, Z. T., Peng, S. Z., Hao, Q. Z., Biscaye, P. E., and Liu, T. S. (2001). Origin of the Miocene-Pliocene Red-Earth formation at Xifeng in Northern China and implications for paleoenvironments. Palaeogeogr. Palaeoclimatol. Palaeoecol. 170, 11-26. doi: 10.1016/S0031-0182(01)00235-8

Guo, Z. T., Ruddiman, W. F., Hao, Q. Z., Wu, H. B., Qiao, Y. S., Zhu, R. X., et al. (2002). Onset of Asian desertification by $22 \mathrm{Myr}$ ago inferred from loess deposits in China. Nature 416, 159-163. doi: 10.1038/416159a

Hao, Q. Z., and Guo, Z. T. (2007). Magnetostratigraphy of an early-middle Miocene loess-soil sequence in the western Loess Plateau of China. Geophys. Res. Lett. 34:L18305. doi: 10.1029/2007gl031162

Hao, Q. Z., Oldfield, F., Bloemendal, J., Torrent, J., and Guo, Z. T. (2009). The record of changing hematite and goethite accumulation over the past 22 Myr on the Chinese Loess Plateau from magnetic measurements and diffuse reflectance spectroscopy. J. Geophys. Res. 114, B12101. doi: 10.1029/2009jb 006604

Heller, F., and Evans, M. E. (1995). Loess magnetism. Rev. Geophys. 33, 211-240. doi: 10.1029/95RG00579

Heslop, D., and Dillon, M. (2007). Unmixing magnetic remanence curves without a priori knowledge. Geophys. J. Int. 170, 556-566. doi: 10.1111/j.1365246X.2007.03432.x

Heslop, D., Langereis, C. G., and Dekkers, M. J. (2000). A new astronomical timescale for the loess deposits of Northern China. Earth Planet. Sci. Lett. 184, 125-139. doi: 10.1016/S0012-821X(00)00324-1

Horton, B. K., Dupont-Nivet, G., Zhou, J., Waanders, G. L., Butler, R. F., and Wang, J. (2004). Mesozoic-Cenozoic evolution of the Xining-Minhe and Dangchang basins, northeastern Tibetan Plateau: Magnetostratigraphic and biostratigraphic results. J. Geophys. Res. 109, B04402. doi: 10.1029/2003jb002913

Huybers, P., and Curry, B. (2006). Links between annual, Milankovitch, and continuum temperature variability. Nature 441, 329-332 doi: $10.1038 /$ nature 04745

Kerr, R. (2007). Global warming: how urgent is climate change? Science, 318 1230-1231. doi: 10.1126/science.318.5854.1230
King, J., and Channell, J. (1991). Sedimentary magnetism, environmental magnetism, and magnetostratigraphy. Rev. Geophys. 39, 358-370.

Kukla, G., Heller, F., Liu, X., Xu, T., Liu, T. S., and An, Z. S. (1988). Pleistocene climates in China dated by magnetic susceptibility. Geology 16, 811-814.

Laskar, J. (1990). The chaotic motion of the solar system: a numerical estimate of the size of the chaotic zones. Icarus 88, 266-291. doi: 10.1016/00191035(90)90084-M

Lawrence, K., Liu, Z., and Herbert, T. (2006). Evolution of the eastern Tropical Pacific through Plio-Pleistocene glaciation. Science 312, 79-83. doi: $10.1126 /$ science. 1120395

Li, J. J., Fang, X. M., Van der Voo, R., Zhu, J. J., Mac Niocaill, C., Cao, J. X., et al. (1997). Late Cenozoic magnetostratigraphy (11-0 Ma) of the Dongshanding and Wangjiashan section in the Longzhong Basin, western China. Geol. Mijubouw 76, 121-134. doi: 10.1023/A:1003153717799

Lisiecki, L. E., and Raymo, M. E. (2005). A Plio-Pleistocene stack of 57 globally distributed benthic d180 records. Paleoceanography 20:PA1003. doi: 10.1594/PANGAEA.704257

Liu, Q., Barrón, V., Torrent, J., Eeckhout, S. G., and Deng, C. (2008). Magnetism of intermediate hydromaghemite in the transformation of 2-line ferrihydrite into hematite and its paleoenvironmental implications. J. Geophys. Res. 113, B01103. doi: 10.1029/2007jb005207

Liu, Q., Deng, C., Torrent, J., and Zhu, R. X. (2007). Review of recent development in mineral magnetism of the Chinese loess. Quat. Sci. Rev. 26, 368-385. doi: 10.1016/j.quascirev.2006.08.004

Liu, Q. S., Roberts, A. P., Larrasoana, J. C., Banerjee, S. K., Guyodo, Y., Tauxe, L., et al. (2012). Environmental magnetism: principles and applications. Rev. Geophys. 50, RG4002. doi: 10.1029/2012rg000393

Liu, T. S. (1985). Loess and the Environment. Beijing: China Ocean.

Liu, T. S., Ding, Z. L., and Rutter, N. (1999). Comparison of Milankovitch periods between continental loess and deep sea records over the last 2.5 Ma. Quat. Sci. Rev. 18, 1205-1212. doi: 10.1016/S0277-3791(98)00110-3

Liu, X. M., Rolph, T., Bloemendal, J., Shaw, J., and Liu, T. S. (1995). Quantitative estimates of palaeoprecipitation at Xifeng, in the Loess Plateau of China. Palaeogeogr. Palaeoclimatol. Palaeoecol. 113, 243-248. doi: 10.1016/00310182(95)00053-O

Liu, X., Rolph, T. C., An, Z. S., and Hesse, P. (2003). Paleoclimatic significance of magnetic proporties on the Red Clay underlying the loess and paleosols in China. Palaeogeogr. Palaeoclimatol. Palaeoecol. 199, 153-166. doi: 10.1016/S0031-0182(03)00504-2

Liu, X., Xu, T., and Liu, T. (1988). The Chinese loess in Xifeng, II. A study of anisotropy of magnetic susceptibility of loess from Xifeng. Geophys. J. 92, 349-353. doi: 10.1111/j.1365-246X.1988.tb01147.x

Long, X., Ji, J., Balsam, W., Barrón, V., and Torrent, J. (2015). Grain growth and transformation of pedogenic magnetic particles in red Ferralsols. Geophys. Res. Lett. 42, 5762-5770. doi: 10.1002/2015GL064678

Lu, H. Y., Vandenberghe, J., and An, Z. S. (2001). Aeolian origin and palaeoclimatic implications of the 'Red Clay' (north China) as evidenced by grain-size distribution. J. Quat. Sci. 16, 89-97. doi: 10.1002/10991417(200101)16:1<89::AID-JQS578>3.0.CO;2-8

Lü, L. Q., Fang, X. M., Mason, A. J., Li, J. J., and An, Z. S. (2001). The evolution of coupling of Asian winter monsoon and high latitude climate of Northern Hemisphere. Sci. Chin. D 44 (Supp. 1), 185-191. doi: $10.1007 /$ BF02911986

Maher, B., and Hu, M. (2006). A high-resolution record of Holocene rainfall variations from the western Chinese Loess Plateau: antiphase behaviour of the African/Indian and East Asian summer monsoons. Holocene 16, 309-319. doi: 10.1191/0959683606hl929rp

Maher, B. A., Thompson, R., and Zhou, L. P. (1994). Spatial and temporal reconstructions of changes in the Asian palaeomonsoon - a new mineral magnetic approach. Earth Planet. Sci. Lett. 125, 461-471. doi: 10.1016/0012$821 \mathrm{X}(94) 90232-1$

Motoi, T., and Chan, W.-L. (2010). Colder Subarctic Pacific with larger sea ice caused by closure of the Central American Seaway and its influence on the East Asian monsoon: a climate model study. Geol. Soc., Lond. Spec. Pub. 342, 265-277. doi: 10.1144/SP342.15

Nie, J., Jackson, M., King, J., and Fang, X. (2013a). Characterizing the superparamagnetic grain distribution of Chinese red-clay sequences by thermal fluctuation tomography. Global Planet. Change 110, 364-367. doi: 10.1016/j.gloplacha.2013.04.012 
Nie, J., King, J., and Fang, X. (2007). Enhancement mechanisms of magnetic susceptibility in the Chinese Red-Clay sequence. Geophys. Res. Lett. 34, L19705. doi: 10.1029/2007GL031430

Nie, J., King, J., and Fang, X. (2008a). The correlation between the magnetic susceptibility record of the Chinese aeolian sequences and the marine benthic oxygen isotope record. Geochem. Geophys. Geosyst. 9, Q12026. doi: 10.1029/2008GC002243

Nie, J., King, J., and Fang, X. (2008b). Link between benthic oxygen isotopes and magnetic susceptibility in the red-clay sequence on the Chinese Loess Plateau. Geophys. Res. Lett. 35, L03703. doi: 10.1029/2007GL032817

Nie, J., King, J., and Fang, X. (2008c). Tibetan uplift intensified the 400 k.y. signal in paleoclimate records at $4 \mathrm{Ma}$. Geol. Soc. Am. Bull. 120, 1338-1344. doi: 10.1130/B26349.1

Nie, J., King, J., Jackson, M., Fang, X., and Song, Y. (2008d). AC magnetic susceptibility studies of the Chinese red-clay sediments between 4.8-4.1 Ma and their paleoceanographic and paleoclimatic implications. J. Geophys. Res. 113, B10106. doi: 10.1029/2008JB005654

Nie, J., Peng, W., Möller, A., Song, Y., Stockli, D. F., Stevens, T., et al. (2014a). Provenance of the upper Miocene-Pliocene red clay deposits of the Chinese loess plateau. Earth Planet. Sci. Lett. 407, 35-47. doi: 10.1016/j.epsl.2014.09.026

Nie, J. S. (2011). Coupled 100-kyr cycles between 3 and $1 \mathrm{Ma}$ in terrestrial and marine paleoclimatic records. Geochem. Geophys. Geosyst. 12, Q10Z32. doi: 10.1029/2011GC003772

Nie, J., Song, Y., King, J. W., Fang, X., and Heil, C. (2010). HIRM variations in the Chinese red-clay sequence: insights into pedogenesis in the dust source area. J. Asian Earth Sci. 38, 96-104. doi: 10.1016/j.jseaes.2009.11.002

Nie, J., Song, Y., King, J. W., Zhang, R., and Fang, X. (2013b). Six million years of magnetic grain-size records reveal that temperature and precipitation were decoupled on the Chinese Loess Plateau during 4.5-2.6 Ma. Quat. Res. 79, 465-470. doi: 10.1016/j.yqres.2013.01.002

Nie, J., Stevens, T., Rittner, M., Stockli, D., Garzanti, E., Limonta, M., et al. (2015). Loess Plateau storage of Northeastern Tibeta Plateau-derived Yellow River sediment. Nat. Commun. 6, 8511. doi: 10.1038/ncomms9511

Nie, J., Stevens, T., Song, Y., King, J., Zhang, R., Ji, S., et al. (2014b). Pacific freshening drives Pliocene cooling and Asian monsoon intensification. Sci. Rep. 4:5474. doi: $10.1038 /$ srep05474

Nie, J., Zhang, R., Necula, C., Heslop, D., Liu, Q., Gong, L., et al. (2014c). Late Miocene-early Pleistocene paleoclimate history of the Chinese Loess Plateau revealed by remanence unmixing. Geophys. Res. Lett. 41, 2163-2168. doi: 10.1002/2014GL059379

Piotrowski, A., Goldstein, S., Hemming, S., and Fairbanks, R. (2005). Temporal Relationships of carbon cycling and ocean circulation at glacial boundaries. Science 307, 1933-1938. doi: 10.1126/science.1104883

Pullen, A., Kapp, P., McCallister, A. T., Chang, H., Gehrels, G. E., Garzione, C. N., et al. (2011). Qaidam basin and northern Tibetan Plateau as dust sources for the Chinese Loess Plateau and paleoclimatic implications. Geology 39, 1031-1034. doi: 10.1130/G32296.1

Qiang, X. K., An, Z. S., Song, Y. G., Chang, H., Sun, Y. B., Liu, W. G., et al. (2011). New eolian red clay sequence on the western Chinese Loess Plateau linked to onset of Asian desertification about $25 \mathrm{Ma}$ ago. Sci. Chin. 54, 136-144. doi: 10.1007/s11430-010-4126-5

Qiang, X. K., Li, Z. X., Powell, C. M., and Zheng, H. B. (2001). Magnetostratigraphic record of the Late Miocene onset of the East Asian monsoon, and Pliocene uplift of northern Tibet. Earth Planet. Sci. Lett. 187, 83-93. doi: 10.1016/S0012-821X(01)00281-3

Raymo, M. E. (1994). The initiation of Northern Hemisphere glaciation. Annu. Rev. Earth Planet. Sci. 22, 353-383. doi: 10.1146/annurev.ea.22.050194.002033

Ruddiman, W. F. (2000). Earth's Climate: Past and Future. New York, NY: Freeman

Schwertmann, U., and Taylor, R. M. (1989). "Iron oxides," in Minerals in Soil Environments, eds J. B. Dixon and S. B. Weed (Madison, WI: Soil Science Society of America), 379-438.

Shackleton, N. J., Berger, A., and Peltier, W. R. (1990). An alternative astronomical calibration of the lower Pleistocene timescale based on ODP Site 677. Trans. $R$. Soc. Edinburgh, Earth Sci. 81, 251-261. doi: 10.1017/S0263593300020782

Shackleton, N. J., Hall, M. A., and Pate, D. (1995). "Pliocene stable isotope stratigraphy of Site 846," in Proceedings of Ocean Drilling Science Results, eds N. G. Pisias, L. A. Janacek, A. Palmer-Julson, and T. H. Van Andel (College Station, TX: Ocean Drilling Program), 337-355.
Sloan, L. C., Crowley, T. J., and Pollard, D. (1996). Modeling of middle Pliocene climate with the NCAR GENESIS general circulation model. Mar. Micropaleo. 27, 51-61. doi: 10.1016/0377-8398(95)00063-1

Song, Y., Fang, X., Li, J. J., An, Z. S., and Miao, X. (2001). The Late Cenozoic uplift of the Liupan Shan, China. Sci. Chin. D 44(Supp.), 176-184. doi: 10.1007/bf02911985

Song, Y., Fang, X., Torii, M., Ishikawa, N., Li, J. J., and An, Z. S. (2007). Late Neogene rock magnetic record of climatic variation from Chinese eolian sediments related to uplift of the Tibetan Plateau. J. Asian Earth Sci. 30, 324-332. doi: 10.1016/j.jseaes.2006.10.004

Stevens, T., Carter, A., Watson, T. P., Vermeesch, P., Lu, H., Ando, S., et al. (2013). Genetic linkage between the Yellow River, the Mu Us desert, and the Chinese Loess Plateau. Quat. Sci. Rev. 78, 355-368. doi: 10.1016/j.quascirev.2012. 11.032

Stevens, T., Palk, C., Carter, A., Lu, H. Y., and Clift, P. D. (2010). Assessing the provenance of loess and desert sediments in northern China using U-Pb dating and morphology of detrital zircons. Geol. Soc. Am. Bull. 122, 1331-1344. doi: 10.1130/B30102.1

Sun, D. H., Shaw, J., An, Z. S., Chen, M., and Yue, L. (1998). Magnetostratigraphy and paleoclimatic interpratation of a continuous 7.2 Ma Late Cenozoic eolian sediments from the Chinese Loess Plateau. Geophys. Res. Lett. 25, 85-88. doi: 10.1029/97GL03353

Sun, Y., Clemens, S. C., An, Z. S., and Yu, Z. (2006). Astronomical timescale and palaeoclimatic implication of stacked 3.6-Myr monsoon records from the Chinese Loess Plateau. Quat. Sci. Rev. 25, 33-48. doi: 10.1016/j.quascirev.2005.07.005

Tiedemann, R., Sarnthein, M., and Shackleton, N. J. (1994). Astronomic timescale for the Pliocene Atlantic $\mathrm{d} 18 \mathrm{O}$ and dust flux records of ODP Site 659. Paleoceanography 9, 619-638. doi: 10.1029/94 PA00208

Torrent, J., Barrón, V., and Liu, Q. (2006). Magnetic enhancement is linked to and precedes hematite formation in aerobic soil. Geophys. Res. Lett. 33, L02401. doi: 10.1029/2005GL024818

Verosub, K., Fine, P., Singer, M., and TenPas, J. (1993). Pedogenesis and paleoclimate: interpretation of the magnetic susceptibility record of Chinese loess-paleosol sequences. Geology, 21, 1011-1014. doi: 10.1130/00917613(1993)021<1011:PAPIOT > 2.3.CO;2

Verosub, K. L., and Roberts, A. P. (1995). Environmental magnetism: Past, present, and future. J. Geophys. Res. 100, 2175-2192. doi: 10.1029/94JB02713

Xu, Y., Yue, L. P., Li, J. X., Sun, L., Sun, B., Zhang, J. Y., et al. (2009). An 11-Maold red clay sequence on the Eastern Chinese Loess Plateau. Palaeogeogr. Palaeoclimatol. Palaeoecol. 284, 383-391. doi: 10.1016/j.palaeo.2009. 10.023

Yang, S. L., and Ding, Z. L. (2010). Drastic climatic shift at $\sim 2.8 \mathrm{Ma}$ as recorded in eolian deposits of China and its implications for redefining the PliocenePleistocene boundary. Quat. Int. 219, 37-44. doi: 10.1016/j.quaint.2009.10.029

Zachos, J., Pagani, M., Sloan, L., Thomas, E., and Billups, K. (2001). Trends, rhythms, and aberrations in global climate $65 \mathrm{Ma}$ to present. Science 292, 686-693. doi: 10.1126/science.1059412

Zheng, D., Zhang, P.-Z., Wan, J., Yuan, D., Li, C., Yin, G., et al. (2006) Rapid exhumation at $\sim 8 \mathrm{Ma}$ on the Liupan Shan thrust fault from apatite fission-track thermochronology: Implications for growth of the northeastern Tibetan Plateau margin. Earth Planet. Sci. Lett. 248, 198-208. doi: 10.1016/j.epsl.2006.05.023

Zhou, L., Oldfield, F., Wintle, A., Robinson, S., and Wang, J. T. (1990). Partly pedogenic origin of magnetic variations in Chinese loess. Nature 346, 737-739. doi: $10.1038 / 346737 \mathrm{a} 0$

Conflict of Interest Statement: The authors declare that the research was conducted in the absence of any commercial or financial relationships that could be construed as a potential conflict of interest.

Copyright (C) 2016 Nie, Song and King. This is an open-access article distributed under the terms of the Creative Commons Attribution License (CC BY). The use, distribution or reproduction in other forums is permitted, provided the original author(s) or licensor are credited and that the original publication in this journal is cited, in accordance with accepted academic practice. No use, distribution or reproduction is permitted which does not comply with these terms. 